\title{
Possible Role of Inadequate Quantities of Intra-Thyroidal Bromine, Calcium and Magnesium in the Etiology of Female Subclinical Hypothyroidism
}

\author{
Zaichick Vladimir ${ }^{1 *}$ and Zaichick Sofia ${ }^{2}$ \\ ${ }^{1}$ Radionuclide Diagnostics Department, Medical Radiological Research Centre, Russia \\ ${ }^{2}$ Laboratory of Dr. Gabriela Caraveo Piso, Feinberg School of Medicine, Northwestern University, USA
}

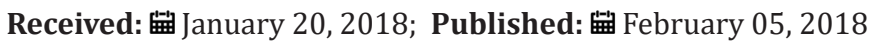

*Corresponding author: V Zaichick, Medical Radiological Research Centre, Korolyev St.4, Obninsk 249036, Kaluga Region, Russia, Tel: (48439) 60289; Fax: (495) 956 1440; Email: vezai@obninsk.com/vzaichick@gmail.com

\begin{abstract}
Objective: Subclinical hypothyroidism does affect fertility. The prevalence of subclinical hypothyroidism is 10-15 times more common in women than in men. Many chemical elements play important role in thyroid function and fertility. The aim of this exploratory study was to evaluate whether significant differences of chemical element contents exist between female and male thyroids and how they can be related to the etiology of subclinical hypothyroidism.

Methods: Thyroid tissue levels of $\mathrm{Br}, \mathrm{Ca}, \mathrm{Cl}, \mathrm{I}, \mathrm{K}, \mathrm{Mg}$, Mn, and $\mathrm{Na}$ were prospectively evaluated in 105 healthy persons (33 females and 72 males). Tissue samples were used for chemical element measurements, employing instrumental neutron activation analysis with high resolution spectrometry of short-lived radionuclides.
\end{abstract}

Results: It was found that the Br thyroid content of females was significantly higher than that of males, while the Ca and Mg contents were lower.

Conclusion: Inappropriate content of intra-thyroidal $\mathrm{Br}$, Ca and $\mathrm{Mg}$ can be associated with the etiology of female subclinical hypothyroidism.

Keywords: Subclinical hypothyroidism; Female Thyroid; Chemical Elements; Neutron activation analysis

\section{Introduction}

Adequate thyroid function is important to maintain normal reproduction, because thyroid dysfunction affects fertility in various ways resulting in abnormal ovulatory cycles, luteal phase defects, high prolactin levels, and sex hormone imbalances $[1,2]$. Therefore, normal thyroid function is necessary for fertility, and to sustain a healthy pregnancy [2]. From large population studies, which measured thyroid function, and systematic reviews of this subject carried out in the 1990s to 2010s, it is known that untreated hypothyroidism is a common condition all over the world [2-11]. The prevalence of subclinical hypothyroidism (SCH) is between $1 \%$ and $10 \%$ in different countries [2-11] and almost everywhere it is 10-15 times more common in women than in men $[4,10]$. Form such a great gender-related difference in the prevalence of SCH arises a question about a specific sensitivity of female thyroid tissue to some external and internal factors.
Although the etiology of SCH and other thyroidal disorders is unknown in detail, several risk factors including deficiency or excess of such micronutrients as iodine (I) has been well identified [1223]. Besides I involved in thyroid function, other chemical elements (ChE) also play important roles such as stabilizers, structural elements, maintenance and regulation of cell function, gene regulation, enzyme cofactors, activation or inhibition of enzymatic reactions, normal peripheral utilization of thyroid hormones and regulation of cell membrane function [24]. Essential or toxic properties of ChE depend on tissue-specific need or tolerance, respectively [25]. Both ChE deficiencies as well as overexposures may disturb the thyroidal cell functions [25]. Moreover, each individual ChE affects the homeostasis of other ChE as some of them share and compete for specific protein transporters and binding proteins, such as metallothioneins. The effect of these interactions 
can be synergistic or antagonistic. Therefore, besides measuring only total amounts of ChE, the interrelationship of ChE should be taken into account to allow for a more comprehensive description of the ChE impact on thyroid health status.

The reliable data on ChE mass fractions in normal human thyroid separately for female and male gland is apparently extremely limited. There are a few studies regarding ChE content in human thyroid, using chemical techniques and instrumental methods [26-37]. However, the majority of these data are based on measurements of processed tissue and in many studies tissue samples are ashed before analysis. In other cases, thyroid samples are treated with solvents (distilled water, ethanol etc) and then are dried at a high temperature for many hours. There is evidence that certain quantities of ChE are lost as a result of such treatment [3840]. Moreover, only a few of these studies employed quality control using certified/standard reference materials (CRM/SRM) for determination of the ChE mass fractions. Sample-nondestructive technique such as instrumental neutron activation analysis with high resolution spectrometry of short-lived radionuclides (INAASLR) is good alternatives for multi-element determination in the samples of thyroid parenchyma.

This work had three aims. The primary purpose of this study was to determine reliable values for such $\mathrm{ChE}$ as bromine (Br), calcium $(\mathrm{Ca})$, chlorine $(\mathrm{Cl})$, iodine $(\mathrm{I})$, potassium $(\mathrm{K})$, magnesium $(\mathrm{Mg})$, manganese $(\mathrm{Mn})$, and sodium $(\mathrm{Na})$ contents in intact (normal) thyroid gland of apparently healthy persons using INAA-SLR analysis. The second aim was to compare the levels of ChE in the thyroid tissue of females and males. The final aim was to find and compare the inter-correlations of ChE in normal thyroid of females and males. All studies were approved by the Ethical Committees of the Medical Radiological Research Centre, Obninsk.

\section{Material and Methods}

Samples of the human thyroid were obtained from randomly selected autopsy specimens of 33 females (European-Caucasian, aged 3.5 to 87 years) and 72 males (European-Caucasian, aged 2.0 to 80 years). All the deceased were citizens of Obninsk and had undergone routine autopsy at the Forensic Medicine Department of City Hospital, Obninsk. Age ranges for subjects were divided into two age groups, with group 1 ( $>40$ years), and group 2 ( $>40$ years). For females in group $1(n=11)$ mean age $( \pm$ standard error of mean, SEM) was $30.9 \pm 3.1$ years and in group $2(n=22)$ mean age was $66.3 \pm 2.7$ years. For males in group $1(n=36)$ mean age was $22.5 \pm 1.4$ years and in group $2(n=36)$ mean age was $52.4 \pm 2.4$ years. These groups were selected to reflect the condition of thyroid tissue in the children, teenagers, young adults and first period of adult life (group 1) and in the second period of adult life as well as in old age (group 2). The available clinical data were reviewed for each subject. None of the subjects had a history of an intersex condition, endocrine disorder, or other chronic disease that could affect the normal development of the thyroid. None of the subjects were receiving medications or used any supplements known to affect thyroid trace element contents. The typical causes of sudden death of most of these subjects included trauma or suicide and also acute untreated illness (cardiac insufficiency, stroke, embolism of pulmonary artery, alcohol poisoning).

All right lobes of thyroid glands were divided into two portions using a titanium scalpel [41]. One tissue portion was reviewed by an anatomical pathologist while the other was used for the ChE content determination. A histological examination was used to control the age norm conformity as well as the unavailability of microadenomatosis and latent cancer. After the samples intended for ChE analysis were weighed, they were freeze-dried and homogenized [42-44]. The pounded sample weighing about 100 mg was used for chemical element measurement by INAA-SLR. The samples for INAA-SLR were sealed separately in thin polyethylene films washed beforehand with acetone and rectified alcohol. The sealed samples were placed in labeled polyethylene ampoules.

To determine contents of the elements by comparison with a known standard, biological synthetic standards (BSS) prepared from phenol-formaldehyde resins were used [45]. In addition to BSS, aliquots of commercial, chemically pure compounds were also used as standards. Ten certified reference material (CRM) IAEA H-4 (animal muscle) sub-samples weighing about $100 \mathrm{mg}$ were treated and analyzed in the same conditions that thyroid samples to estimate the precision and accuracy of results.

The content of $\mathrm{Br}, \mathrm{Ca}, \mathrm{Cl}, \mathrm{I}, \mathrm{K}, \mathrm{Mg}$, Mn, and Na were determined by INAA-SLR using a horizontal channel equipped with the pneumatic rabbit system of the WWR-c research nuclear reactor. The neutron flux in the channel was $1.7 \times 10^{13} \mathrm{ncm}^{-2} \mathrm{~s}^{-1}$. Ampoules with thyroid tissue samples, SSB, intralaboratory-made standards, and certified reference material were put into polyethylene rabbits and then irradiated separately for 180s. Copper foils were used to assess neutron flux. The measurement of each sample was made twice, 1 and 120min after irradiation. The duration of the first and second measurements was 10 and $20 \mathrm{~min}$, respectively. A coaxial $98-\mathrm{cm}^{3} \mathrm{Ge}$ (Li) detector and a spectrometric unit (NUC 8100), including a PCcoupled multichannel analyzer, were used for measurements. The spectrometric unit provided $2.9 \mathrm{keV}$ resolution at the ${ }^{60} \mathrm{Co} 1,332-\mathrm{keV}$ line. Details of used nuclear reactions, radionuclides, and gammaenergies were presented in our earlier publications concerning the INAA chemical element contents in human prostate and scalp hair [46-49].

A dedicated computer program for INAA mode optimization was used [50]. All thyroid samples were prepared in duplicate, and mean values of ChE contents were used in final calculation. Using Microsoft Office Excel software, a summary of the statistics, including, arithmetic mean, standard deviation, standard error of mean, minimum and maximum values, median, percentiles with 0.025 and 0.975 levels was calculated for ChE contents in thyroid tissue samples of females and males. The difference in the results 
between females and males (age group 1 and 2 combined), as well as between females and males separately in age group 1 and

\section{Results}

Table 1: Neutron activation analysis data of chemical element contents in the IAEA H-4 (animal muscle) reference material compared to certified values (mg/ $\mathrm{kg}$, dry mass basis).

\begin{tabular}{|c|c|c|c|c|}
\hline \multirow[t]{2}{*}{ Element } & \multirow{2}{*}{$\begin{array}{c}\text { This work results } \\
\text { Mean } \pm \text { SD }\end{array}$} & \multicolumn{3}{|c|}{ Certified values } \\
\hline & & Mean & $95 \%$ confidence interval & Type \\
\hline $\mathrm{Br}$ & $5.0 \pm 0.9$ & 4.1 & $3.5-4.7$ & $\mathrm{~N}$ \\
\hline $\mathrm{Ca}$ & $238 \pm 59$ & 188 & $163-213$ & $\mathrm{~N}$ \\
\hline $\mathrm{Cl}$ & $1950 \pm 230$ & 1890 & $1810-1970$ & $\mathrm{~N}$ \\
\hline I & $<1.0$ & 0.08 & - & $\mathrm{N}$ \\
\hline $\mathrm{K}$ & $16200 \pm 3800$ & 15800 & $15300-16400$ & $\mathrm{C}$ \\
\hline $\mathrm{Mg}$ & $1100 \pm 190$ & 1050 & $990-1110$ & $\mathrm{C}$ \\
\hline $\mathrm{Mn}$ & $0.55 \pm 0.11$ & 0.52 & $0.48-0.55$ & $\mathrm{C}$ \\
\hline $\mathrm{Na}$ & $2190 \pm 140$ & 2060 & $1930-2180$ & $\mathrm{C}$ \\
\hline
\end{tabular}

Mean - arithmetical mean, SD - standard deviation, C - certified values, N - non-certified values.

Table 1 depicts our data for eight ChE in ten sub-samples of CRM IAEA H-4 (animal muscle) and the certified values of this material. Table 2 presents certain statistical parameters (arithmetic mean, standard deviation, standard error of mean, minimal and maximal values, median, percentiles with 0.025 and 0.975 levels) of the $\mathrm{Br}$, $\mathrm{Ca}, \mathrm{Cl}, \mathrm{I}, \mathrm{K}, \mathrm{Mg}, \mathrm{Mn}$, and Na mass fraction in normal thyroid tissue of female and male. The comparison of our results with published data for $\mathrm{Br}, \mathrm{Ca}, \mathrm{Cl}, \mathrm{I}, \mathrm{K}, \mathrm{Mg}, \mathrm{Mn}$, and Na mass fraction in normal human thyroid is shown in Table 3. The ratios of means and the difference group 2 was evaluated by the parametric Student's t-test and nonparametric Wilcoxon-Mann-Whitney U-test.

Table 2: Some statistical parameters of $\mathrm{Br}, \mathrm{Ca}, \mathrm{Cl}, \mathrm{I}, \mathrm{K}, \mathrm{Mg}, \mathrm{Mn}$, and $\mathrm{Na}$ mass fractions (mg/kg, dry mass basis) in normal thyroid tissue of females and males.

\begin{tabular}{|c|c|c|c|c|c|c|c|c|c|}
\hline Gender & Element & Mean & SD & SEM & Min & Max & Median & P 0.025 & P 0.975 \\
\hline Males & $\mathrm{Br}$ & 13.7 & 7.8 & 1.0 & 1.90 & 32.3 & 10.2 & 2.50 & 30.7 \\
\hline $\mathrm{n}=72$ & $\mathrm{Ca}$ & 1703 & 1048 & 131 & 414 & 6230 & 1470 & 452 & 4163 \\
\hline & $\mathrm{Cl}$ & 3449 & 1450 & 219 & 1030 & 5920 & 3470 & 1262 & 5657 \\
\hline & $\mathrm{I}$ & 1786 & 940 & 118 & 220 & 4205 & 1742 & 239 & 3808 \\
\hline & $\mathrm{K}$ & 6289 & 2594 & 329 & 2440 & 14300 & 5670 & 2622 & 12670 \\
\hline & $\mathrm{Mg}$ & 306 & 143 & 19 & 99.0 & 930 & 287 & 107 & 572 \\
\hline & $\mathrm{Mn}$ & 1.31 & 0.49 & 0.07 & 0.510 & 2.30 & 1.30 & 0.534 & 2.21 \\
\hline & $\mathrm{Na}$ & 6820 & 1781 & 214 & 3050 & 13453 & 6680 & 3861 & 11350 \\
\hline $\mathrm{Females}$ & $\mathrm{Br}$ & 22.4 & 16.1 & 3.2 & 5.00 & 66.9 & 16.3 & 5.00 & 59.2 \\
\hline $\mathrm{n}=33$ & $\mathrm{Ca}$ & 1663 & 570 & 198 & 461 & 3640 & 1170 & 670 & 3600 \\
\hline & $\mathrm{Cl}$ & 3317 & 1480 & 290 & 1200 & 6000 & 3375 & 1388 & 5906 \\
\hline & $\mathrm{I}$ & 1956 & 1199 & 219 & 114 & 5061 & 1562 & 309 & 4662 \\
\hline & $\mathrm{K}$ & 5395 & 3245 & 723 & 1740 & 13700 & 4835 & 2120 & 13230 \\
\hline & $\mathrm{Mg}$ & 212 & 97 & 24 & 66.0 & 364 & 215 & 67.5 & 356 \\
\hline & $\mathrm{Mn}$ & 1.50 & 0.84 & 0.22 & 0.550 & 4.18 & 1.37 & 0.603 & 3.41 \\
\hline & $\mathrm{Na}$ & 6421 & 1721 & 320 & 3800 & 10450 & 6700 & 4122 & 9924 \\
\hline
\end{tabular}

Mean - arithmetic mean, SD - standard deviation, SEM - standard error of mean, Min - minimum value, Max - maximum value, $\mathrm{P}$ 0.025 - percentile with 0.025 level, P 0.975 - percentile with 0.975 level. 
Table 3: Median, minimum and maximum value of means of $\mathrm{Br}, \mathrm{Ca}, \mathrm{Cl}, \mathrm{I}, \mathrm{K}, \mathrm{Mg}, \mathrm{Mn}$, and $\mathrm{Na}$ contents in normal human thyroid according to data from the literature in comparison with our results ( $\mathrm{mg} / \mathrm{kg}$, dry mass basis).

\begin{tabular}{|c|c|c|c|c|}
\hline \multirow{2}{*}{ Element } & This work & \multicolumn{3}{|c|}{ Published data [Reference] } \\
\cline { 2 - 5 } & $\begin{array}{c}\text { Females and males } \\
\text { (combined) M } \pm \text { SD }\end{array}$ & Median of means(n)* & $\begin{array}{c}\text { Minimum of means M or } \\
\text { M } \pm \text { SD, (n)** }\end{array}$ & $\begin{array}{c}\text { Maximum of means } \\
\text { M or M } \pm \text { SD, (n)** }\end{array}$ \\
\hline $\mathrm{Br}$ & $16.3 \pm 11.6$ & $18.1(11)$ & $5.12(44)[26]$ & $284 \pm 44(14)[27]$ \\
\hline $\mathrm{Ca}$ & $1692 \pm 1022$ & $1600(17)$ & $840 \pm 240(10)[28]$ & $3800 \pm 320(29)[28]$ \\
\hline $\mathrm{Cl}$ & $3400 \pm 1452$ & $6800(5)$ & $804 \pm 80(4)[29]$ & $8000(-)[30]$ \\
\hline $\mathrm{I}$ & $1841 \pm 1027$ & $1888(95)$ & $159 \pm 8(23)[31]$ & $5772 \pm 2708(50)[32]$ \\
\hline $\mathrm{K}$ & $6071 \pm 2773$ & $4400(17)$ & $46.4 \pm 4.8(4)[29]$ & $6090(17)[33]$ \\
\hline $\mathrm{Mg}$ & $285 \pm 139$ & $390(16)$ & $3.5(-)[34]$ & $840 \pm 400(14)[35]$ \\
\hline $\mathrm{Mn}$ & $1.35 \pm 0.58$ & $1.82(36)$ & $0.44 \pm 11(12)[36]$ & $69.2 \pm 7.2(4)[29]$ \\
\hline $\mathrm{Na}$ & $6702 \pm 1764$ & $8000(9)$ & $438(-)[37]$ & $10000 \pm 5000(11)[35]$ \\
\hline
\end{tabular}

$\mathrm{M}$-arithmetic mean, SD - standard deviation, $(\mathrm{n})^{*}$ - number of all references, $(\mathrm{n})^{* *}$ - number of samples.

Table 4: Differences between mean values $(\mathrm{M} \pm \mathrm{SEM})$ of $\mathrm{Br}, \mathrm{Ca}, \mathrm{Cl}, \mathrm{I}, \mathrm{K}, \mathrm{Mg}$, Mn, and $\mathrm{Na}$ mass fractions (mg/ $\mathrm{kg}$, dry mass basis) in normal thyroid tissue of males and females.

\begin{tabular}{|c|c|c|c|c|c|}
\hline & \multicolumn{4}{|c|}{ Thyroid tissue } & \multirow{2}{*}{$\begin{array}{c}\text { Ratio } \\
\text { Females } \\
\text { to Males }\end{array}$} \\
\hline & $\begin{array}{c}\text { Males } \\
\text { 2.0-80 years } \\
n=72\end{array}$ & $\begin{array}{c}\text { Females } \\
\begin{array}{c}\text { 3.5-87 years } \\
\mathrm{n}=33\end{array}\end{array}$ & $\begin{array}{c}\text { Student's t-test } \\
\mathrm{p} \leq\end{array}$ & $\begin{array}{c}\text { U-test } \\
\text { p }\end{array}$ & \\
\hline $\mathrm{Br}$ & $13.7 \pm 1.0$ & $22.4 \pm 3.2$ & 0.0151 & $\leq 0.01$ & 1.64 \\
\hline $\mathrm{Ca}$ & $1703 \pm 131$ & $1663 \pm 198$ & 0.864 & $>0.05$ & 0.98 \\
\hline $\mathrm{Cl}$ & $3449 \pm 219$ & $3317 \pm 290$ & 0.718 & $>0.05$ & 0.96 \\
\hline I & $1786 \pm 118$ & $1956 \pm 219$ & 0.497 & $>0.05$ & 1.10 \\
\hline $\mathrm{K}$ & $6289 \pm 329$ & $5395 \pm 723$ & 0.271 & $>0.05$ & 0.86 \\
\hline $\mathrm{Mg}$ & $306 \pm 19$ & $212 \pm 24$ & 0.0046 & $\leq 0.01$ & 0.69 \\
\hline Mn & $1.31 \pm 0.07$ & $1.50 \pm 0.22$ & 0.440 & $>0.05$ & 1.15 \\
\hline $\mathrm{Na}$ & $6820 \pm 214$ & $6421 \pm 320$ & 0.304 & $>0.05$ & 0.94 \\
\hline
\end{tabular}

M-arithmetic mean, SEM - standard error of mean, t-test - Student's t-test, U-test - Wilcoxon-Mann-

Table 5: Differences between mean values $(\mathrm{M} \pm \mathrm{SEM})$ of $\mathrm{Br}, \mathrm{Ca}, \mathrm{Cl}, \mathrm{I}, \mathrm{K}, \mathrm{Mg}, \mathrm{Mn}$, and $\mathrm{Na}$ mass fractions (mg/ $\mathrm{kg}$, dry mass basis) in normal thyroid tissue of males and females aged $\leq 40$ years.

\begin{tabular}{|c|c|c|c|c|c|}
\hline \multirow[b]{2}{*}{ Element } & \multicolumn{4}{|c|}{ Thyroid tissue } & \multirow{2}{*}{$\begin{array}{c}\text { Ratio } \\
\text { FG1/MG1 }\end{array}$} \\
\hline & $\begin{array}{c}\text { Males (MG1) } \\
n=44\end{array}$ & Females (FG1) n=11 & Student's t-test $\mathbf{p} \leq$ & U-test p & \\
\hline $\mathrm{Br}$ & $12.5 \pm 1.3$ & $13.3 \pm 2.5$ & 0.793 & $>0.05$ & 1.06 \\
\hline $\mathrm{Ca}$ & $1484 \pm 90$ & $1052 \pm 65$ & 0.0004 & $\leq 0.01$ & 0.71 \\
\hline $\mathrm{Cl}$ & $3236 \pm 314$ & $4109 \pm 544$ & 0.190 & $>0.05$ & 1.27 \\
\hline I & $1601 \pm 146$ & $1876 \pm 346$ & 0.476 & $>0.05$ & 1.17 \\
\hline K & $6549 \pm 386$ & $5379 \pm 1101$ & 0.340 & $>0.05$ & 0.82 \\
\hline $\mathrm{Mg}$ & $309 \pm 19$ & $212 \pm 39$ & 0.048 & $\leq 0.01$ & 0.69 \\
\hline $\mathrm{Mn}$ & $1.46 \pm 0.09$ & $1.43 \pm 0.13$ & 0.816 & $>0.05$ & 0.98 \\
\hline $\mathrm{Na}$ & $6845 \pm 271$ & $5969 \pm 458$ & 0.121 & $>0.05$ & 0.87 \\
\hline
\end{tabular}

M- arithmetic mean, SEM - standard error of mean, t-test - Student's t-test, U-test - Wilcoxon-Mann 


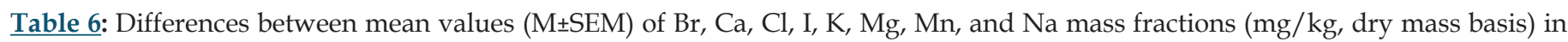
normal thyroid tissue of males and females aged $>40$ years.

\begin{tabular}{|c|c|c|c|c|c|}
\hline \multirow[b]{2}{*}{ Element } & \multicolumn{4}{|c|}{ Thyroid tissue } & \multirow{2}{*}{$\begin{array}{c}\text { Ratio } \\
\text { FG2/MG2 }\end{array}$} \\
\hline & $\begin{array}{c}\text { Males (MG2) } \\
\mathbf{n}=\mathbf{2 8}\end{array}$ & $\begin{array}{c}\text { Females (FG2) } \\
n=22\end{array}$ & $\begin{array}{c}\text { Student's t-test } \\
\mathrm{p} \leq\end{array}$ & $\begin{array}{c}\text { U-test } \\
\mathbf{p}\end{array}$ & \\
\hline $\mathrm{Br}$ & $15.4 \pm 1.7$ & $26.8 \pm 4.3$ & 0.021 & $\leq 0.01$ & 1.74 \\
\hline $\mathrm{Ca}$ & $2003 \pm 278$ & $2029 \pm 276$ & 0.948 & $>0.05$ & 1.01 \\
\hline $\mathrm{Cl}$ & $3662 \pm 305$ & $2965 \pm 318$ & 0.122 & $>0.05$ & 0.81 \\
\hline I & $2048 \pm 190$ & $2002 \pm 288$ & 0.895 & $>0.05$ & 0.98 \\
\hline $\mathrm{K}$ & $5929 \pm 577$ & $5408 \pm 1013$ & 0.661 & $>0.05$ & 0.91 \\
\hline $\mathrm{Mg}$ & $301 \pm 39$ & $212 \pm 31$ & 0.085 & $\leq 0.05$ & 0.70 \\
\hline $\mathrm{Mn}$ & $1.11 \pm 0.08$ & $1.57 \pm 0.46$ & 0.359 & $>0.05$ & 1.41 \\
\hline $\mathrm{Na}$ & $6784 \pm 355$ & $6025 \pm 414$ & 0.772 & $>0.05$ & 0.89 \\
\hline
\end{tabular}

M - arithmetic mean, SEM - standard error of mean, t-test - Student's t-test, U-test - Wilcoxon-Mann-Whitney U-test.

Table 7: Intercorrelations of the chemical element mass fractions in the normal thyroid of females and males ( $\mathrm{r}-$ coefficient of correlation).

\begin{tabular}{|c|c|c|c|c|c|c|c|c|c|}
\hline Gender & Element & Br & Ca & Cl & I & K & Mg & Mn & Na \\
\hline Male & $\mathrm{Br}$ & $\mathbf{1 . 0 0}$ & 0.06 & $-0.26^{\mathrm{a}}$ & 0.05 & 0.03 & -0.08 & 0.09 & -0.08 \\
\hline & $\mathrm{Ca}$ & 0.06 & $\mathbf{1 . 0 0}$ & -0.19 & 0.08 & -0.21 & $0.30^{\mathrm{a}}$ & 0.03 & -0.17 \\
\hline & $\mathrm{Cl}$ & $-0.26 \mathrm{a}$ & -0.19 & $\mathbf{1 . 0 0}$ & 0.08 & $-0.46^{\mathrm{b}}$ & 0.09 & -0.19 & $0.53^{\mathrm{c}}$ \\
\hline & $\mathrm{I}$ & 0.05 & 0.081 & 0.08 & $\mathbf{1 . 0 0}$ & $-0,20$ & -0.21 & -0.14 & -0.10 \\
\hline & $\mathrm{K}$ & 0.03 & -0.21 & $-0.46 \mathrm{~b}$ & $-0,20$ & $\mathbf{1 . 0 0}$ & $0.27^{\mathrm{a}}$ & -0.05 & 0.08 \\
\hline & $\mathrm{Mg}$ & -0.08 & $0.30^{\mathrm{a}}$ & 0.09 & -0.21 & $0.27^{\mathrm{a}}$ & $\mathbf{1 . 0 0}$ & 0.16 & $0.27^{\mathrm{a}}$ \\
\hline & $\mathrm{Mn}$ & 0.09 & 0.03 & -0.19 & 0.14 & -0.05 & 0.16 & $\mathbf{1 . 0 0}$ & -0.01 \\
\hline & $\mathrm{Na}$ & -0.08 & -0.17 & $0.53^{\mathrm{c}}$ & -0.10 & 0.08 & $0.27^{\mathrm{a}}$ & -0.01 & $\mathbf{1 . 0 0}$ \\
\hline & $\mathrm{Br}$ & $\mathbf{1 . 0 0}$ & 0.25 & 0.07 & -0.05 & $0.40^{\mathrm{a}}$ & -0.18 & $0.73^{\mathrm{c}}$ & 0.18 \\
\hline & $\mathrm{Ca}$ & 0.25 & $\mathbf{1 . 0 0}$ & -0.6 & 0.13 & 0.13 & 0.02 & 0.34 & -0.18 \\
\hline & $\mathrm{Cl}$ & 0.07 & $-0.66^{\mathrm{c}}$ & $\mathbf{1 . 0 0}$ & 0.16 & -0.37 & $0.56^{\mathrm{b}}$ & -0.21 & $0.39^{\mathrm{a}}$ \\
\hline & $\mathrm{I}$ & -0.05 & 0.13 & 0.16 & $\mathbf{1 . 0 0}$ & -0.32 & 0.19 & -0.09 & $0.45^{\mathrm{a}}$ \\
\hline & $\mathrm{K}$ & $0.40^{\mathrm{a}}$ & 0.13 & -0.37 & -0.32 & $\mathbf{1 . 0 0}$ & $0.77^{\mathrm{c}}$ & -0.19 & -0.15 \\
\hline & $\mathrm{Mg}$ & -0.18 & 0.021 & $0.56 \mathrm{~b}$ & 0.19 & $0.77^{\mathrm{c}}$ & $\mathbf{1 . 0 0}$ & -0.27 & 0.31 \\
\hline & $\mathrm{Mn}$ & $0.73^{\mathrm{c}}$ & 0.341 & -0.21 & -0.09 & -0.19 & -0.27 & $\mathbf{1 . 0 0}$ & $-0.41^{\mathrm{a}}$ \\
\hline & $\mathrm{Na}$ & 0.18 & -0.18 & $0.39^{\mathrm{a}}$ & $0.45 \mathrm{a}$ & -0.15 & 0.31 & $0.41^{\mathrm{a}}$ & $\mathbf{1 . 0 0}$ \\
\hline
\end{tabular}

Statistically significant values: ${ }^{\mathrm{a}} \mathrm{p} \leq 0.05,{ }^{\mathrm{b}} \mathrm{p} \leq 0.01,{ }^{\mathrm{c}} \mathrm{p} \leq 0.001$.

\section{Discussion}

\section{Precision and accuracy of results}

Good agreement of the $\mathrm{Br}, \mathrm{Ca}, \mathrm{Cl}, \mathrm{I}, \mathrm{K}, \mathrm{Mg}$, $\mathrm{Mn}$, and $\mathrm{Na}$ contents analyzed by INAA-SLR with the certified data of CRM IAEA H-4 (Table 1) indicates an acceptable accuracy of the results obtained in the study of ChE of the thyroid samples presented in Tables 2-7. The mean values and all selected statistical parameters were calculated for eight $\mathrm{ChE}(\mathrm{Br}, \mathrm{Ca}, \mathrm{Cl}, \mathrm{I}, \mathrm{K}, \mathrm{Mg}, \mathrm{Mn}$, and $\mathrm{Na}$ ) mass fractions in thyroid of female and male (Table 2).

\section{Comparison with published data}

Values obtained for $\mathrm{Br}, \mathrm{Ca}, \mathrm{Cl}, \mathrm{I}, \mathrm{K}, \mathrm{Mg}, \mathrm{Mn}$, and $\mathrm{Na}$ contents in the normal human thyroid (Table 3) agree well with median of mean values reported by other researches. Data cited in Table 3 also includes samples obtained from patients who died from different non-endocrine diseases. A number of values for ChE mass fractions were not expressed on a dry mass basis by the authors of the cited references. However, we calculated these values using published data for water (75\%) [55] and ash (4.16\% on dry mass basis) [56] contents in thyroid of adults. The range of means of $\mathrm{Br}$, $\mathrm{Ca}, \mathrm{Cl}, \mathrm{I}, \mathrm{K}, \mathrm{Mg}$, Mn, and Na level reported in the literature for normal human thyroid vary widely (Table 3 ). This can be explained by a dependence of $\mathrm{ChE}$ content on many factors, including the region of the thyroid, from which the sample was taken, age, gender, ethnicity, and mass of the gland. Not all these factors were strictly controlled in cited studies. Another and, in our opinion, leading cause of inter-observer variability can be attributed to the accuracy 
of the analytical techniques, sample preparation methods, and insufficient quality control of results in these studies.

\section{Gender-related differences}

A strongly pronounced difference in $\mathrm{Br}$ and $\mathrm{Mg}$ mass fractions was observed between female and male thyroid (Table 4). The mean $\mathrm{Br}$ mass fraction in female thyroids was 1.6 times higher while the mean of Mg mass fraction was 31\% lower than in male thyroids. During the first 40 years of life (Age group 1) the situation with ChE contents in female thyroids was some different than that for older females. In Age group 1 no statistically significant difference between the Br content of female and male thyroids was found, but differences between their $\mathrm{Ca}$ and Mg contents were detected (Table 5). In Age group 1 of females with mean age 30.9 years the Ca and Mg thyroid contents were about $30 \%$ lower than in thyroid of males from the same age group. For ages over 40 years (Age group 2) a statistically significant difference between the $\mathrm{Br}$ content in female and male thyroid was observed, but differences between the $\mathrm{Ca}$ content in thyroids of females and males, previously found in the Age group 1, was no longer evident (Table 6). However, in this age group a statistically significant reduced level of Mg mass fraction in female thyroids was observed using the non-parametric WilcoxonMann-Whitney U-test. A significant direct inter-correlation between $\mathrm{Ca}$ and $\mathrm{Mg}, \mathrm{K}$ and $\mathrm{Mg}, \mathrm{Mg}$ and $\mathrm{Na}$, and also $\mathrm{Na}$ and $\mathrm{Cl}$, as well as a inverse correlation $\mathrm{Br}$ and $\mathrm{Cl}$ and $\mathrm{Cl}$ and $\mathrm{K}$ mass fractions was seen in male thyroids (Table 7). In female thyroids all correlations between ChE found in male thyroids were not observed, except correlations $\mathrm{Na}$ and $\mathrm{Cl}$ and $\mathrm{K}$ and $\mathrm{Mg}$. However, a few other different correlations were found: a direct correlation, $\mathrm{Br}$ and $\mathrm{K}, \mathrm{Br}$ and $\mathrm{Mn}, \mathrm{Cl}$ and $\mathrm{Mg}$, I and $\mathrm{Na}$, and an inverse correlation, $\mathrm{Ca}$ and $\mathrm{Cl}$ and $\mathrm{Mn}$ and $\mathrm{Na}$.

Because the prevalence of SCH is 10-15 times greater in women than in men $[4,10]$, we can accept the levels and relationships of ChE mass fraction in male thyroid as more suitable (perhaps optimal) for normal function of the gland. If so, we have to conclude that up to age 40 years there is a significant deficiency of $\mathrm{Ca}$ and $\mathrm{Mg}$ contents in female thyroid parenchyma. In age over 40 significant deficiency of $\mathrm{Mg}$ content in female thyroid persist, while the Ca deficiency disappears and an excess of $\mathrm{Br}$ is now seen. Moreover, because inter-correlations of ChE contents reflect their relationships one can deduce that relationships of ChE in female thyroids are certainly less optimal that in males.

a) Bromine: $\mathrm{The} \mathrm{Br}$ is one of the most abundant and ubiquitous of $\mathrm{ChE}$ in the biosphere. Inorganic bromide compounds, especially potassium bromide ( $\mathrm{KBr}$ ), sodium bromide ( $\mathrm{NaBr})$, and ammonium bromide $\left(\mathrm{NH}_{4} \mathrm{Br}\right)$, are frequently used as sedatives in Russia [57]. This may be the reason for elevated levels of $\mathrm{Br}$ in female thyroid, because females particularly if aged over 40 years use sedatives more intensively than males. Inorganic bromide exerts therapeutic as well as toxic effects. An enhanced intake of bromide could interfere with the metabolism of iodine at the whole-body level, for both elements have similar chemical properties, and are adjacent halogens. So in the thyroid gland the biological behavior of bromide is similar to that of iodide [58]. Therefore, an excessive $\mathrm{Br}$ level in the thyroid of elderly females might inhibit thyroid hormonal synthesis.

b) Calcium: Despite the fact that $\mathrm{Ca}$ is the most abundant ChE in a human body its role in thyroid health is poorly understood. However, a significant direct correlation between serum Ca and thyroid stimulating hormone (TSH) level was confirmed by the results of many studies [59-61]. The reduced Ca content in female thyroid parenchyma in comparison with the optimal level characteristic of male thyroid can reflect some deficiency of this element in female body. Thus, a deficiency of Ca inhibits TSH secretion and, as consequence, thyroid function.

c) Magnesium: Current biochemical evidence about the elements required to maintain thyroid function shows that these not only include dietary iodine and selenium (Se) but also $\mathrm{Mg}$, because magnesium-ATP contributes to the active process of iodine uptake [62]. Moreover, Mg deficiency can influence bioavailability and tissue distribution of Se which then appears diminished [63]. Similar $\mathrm{Ca}$, there is a significant direct correlation between serum $\mathrm{Mg}$ and TSH level [59]. From these data, one can conclude that $\mathrm{Mg}$ is involved in the thyroid function. The reduced Ca content in female thyroid parenchyma in comparison with the optimal level characteristic of male thyroid may reflect some deficiency of this element in female body, while a deficiency of Mg has to associate with hypothyroidism. Each of the $\mathrm{ChE}$ is distinct in its primary mode of action. Moreover, there are several forms of synergistic action of the ChE as a part of intracellular metabolism. Thus, in addition to ChE content gender-related differences of relationships between them (inter-correlations) might be also involved in etiology of SCH.

\section{Conclusion}

Our data elucidate that there is a statistically significant genderrelated difference between ChE levels in thyroid tissue of females and males. The $\mathrm{Br}$ mass fraction is higher while the $\mathrm{Ca}$ and $\mathrm{Mg}$ mass fractions are lower in female thyroids compared with those in male thyroids. Subclinical hypothyroidism is a multietiological and multifactorial complex condition. The complete understanding of the role of inadequate levels of some ChE in thyroid parenchyma in the etiology of SCH requires a global vision of their different mechanisms of action, which is not yet possible with the present state of knowledge. However, from the results of our study it follows that an involvement of inadequate contents of intra-thyroidal $\mathrm{Br}, \mathrm{Ca}$ and Mg in the etiology of female SCH may be assumed.

\section{Acknowledgement}

Authors are grateful to Dr. Yu. Choporov, Head of the Forensic Medicine Department of City Hospital, Obninsk, for supplying thyroid samples. 


\section{References}

1. Krassas GE, Poppe K, Glinoer D (2010) Thyroid function and human reproductive health. Endocr Rev 31(5):702-755.

2. Verma I, Sood R, Juneja S, Kaur S (2012) Prevalence of hypothyroidism in infertile women and evaluation of response of treatment for hypothyroidism on infertility. Int J Appl Basic Med Res 2(1): 17-19.

3. Bjoro T, Holmen J, Krüger O, Midthjell K, Hunstad K, et al. (2000) Prevalence of thyroid disease, thyroid dysfunction and thyroid peroxidase antibodies in a large, unselected population. The Health Study of Nord-Trondelag (HUNT). Eur J Endocrinol 143(5): 639-647.

4. Vanderpump MP, Tunbridge WM (2002) Epidemiology and prevention of clinical and subclinical hypothyroidism. Thyroid 12(10): 839-847.

5. Biondi B, Cooper DS (2008) The clinical significance of subclinical thyroid dysfunction. Endocr Rev 29(1): 76-131.

6. Rodondi N, den Elzen WP, Bauer DC, Cappola AR, Razvi S, et al. (2010) Subclinical hypothyroidism and the risk of coronary heart disease and mortality. JAMA 304(12): 1365-1374.

7. Verma I, Sood R, Juneja S, Kaur S (2012) Prevalence of hypothyroidism in infertile women and evaluation of response of treatment for hypothyroidism on infertility. Int J Appl Basic Med Res 2(1): 17-19.

8. Asvold BO, Vatten LJ, Bjøro T (2013) Changes in the prevalence of hypothyroidism: the HUNT Study in Norway. Eur J Endocrinol 169(5): 613-620.

9. Baumgartner C, da Costa BR, Collet TH, Feller M, Floriani C, et al. (2017) Thyroid function within the normal range, subclinical hypothyroidism, and the risk of atrial fibrillation. Circulation 136(22): 2100-2116.

10. Khan MA, Ahsan T, Rehman UL, Jabeen R, Farouq S (2017) Subclinical hypothyroidism: frequency, clinical presentations and treatment indications. Pak J Med Sci 33(4): 818-822.

11. Battikhi MN (2018) Correlation between AMH and TSH in infertile women. EC Gynaecology 7.1: 12-15.

12. Zaichick V, Choporov Yu (1996) Determination of the natural level of human intra-thyroid iodine by instrumental neutron activation analysis. J Radioanal Nucl Chem 207(1): 153-161.

13. Zaichick V, Zaichick S (1997) Normal human intrathyroidal iodine. Sci Total Environ 206(1): 39-56.

14. Zaichick V (1998) Iodine excess and thyroid cancer. J Trace Elem Exp Med 11(4): 508-509.

15. Zaichick V (1998) In vivo and in vitro application of energy-dispersive XRF in clinical investigations: experience and the future. J Trace Elem Exp Med 11(4): 509-510.

16. Zaichick V, Iljina T (1998) Dietary iodine supplementation effect on the rat thyroid 131I blastomogenic action. In: Die Bedentung der Mengenund Spurenelemente. 18. Arbeitstangung. Jena; Friedrich-SchillerUniversität: 294-306.

17. Zaichick V, Zaichick S (1999) Energy-dispersive X-ray fluorescence of iodine in thyroid puncture biopsy specimens. J Trace Microprobe Tech 17(2): 219-232.

18. Zaichick V (1999) Human intrathyroidal iodine in health and nonthyroidal disease. In: New aspects of trace element research. London and Tokyo; Smith-Gordon and Nishimura: 114-119.

19. Zaichick V (2000) Relevance of, and potentiality for in vivo intrathyroidal iodine determination. In Vivo Body Composition Studies. Ann N Y Acad Sci 904: 630-632.
20. Usha Menon V, Sundaram KR, Unnikrishnan AG, Jayakumar RV, Nair V, et al. (2009) High prevalence of undetected thyroid disorders in an iodine sufficient adult south Indian population. J Indian Med Assoc 107(2): 72 77.

21. Zimmermann MB, Boelaert K (2015) Iodine deficiency and thyroid disorders. Lancet Diabetes Endocrinol 3(4): 286-295.

22. Guo Y, Zynat J, Xu Z, Wang X, Osiman R, et al. (2016) Iodine nutrition status and thyroid disorders: a cross-sectional study from the Xinjiang Autonomous Region of China. Eur J Clin Nutr 70(11): 1332-1336.

23. Shan Z, Chen L, Lian X, Liu C, Shi B, et al. (2016) Iodine Status and Prevalence of Thyroid Disorders After Introduction of Mandatory Universal Salt Iodization for 16 Years in China: A Cross-Sectional Study in 10 Cities. Thyroid 26(8): 1125-1130.

24. Zaichick V, Tsyb A, Vtyurin BM (1995) Trace elements and thyroid cancer. Analyst 120(3): 817-821.

25. Zaichick V (2006) Medical elementology as a new scientific discipline. J Radioanal Nucl Chem 269(2): 303-309.

26. Zhu HD, Wang JY, Wu Q Wang NF, Fan TJ, et al. (2010) Element contents in organs and tissues of Chinese adult men. Health Phys 98(1): 61-73.

27. Salimi J, Moosavi K, Vatankhah S, Yaghoobi A (2004) Investigation of heavy trace elements in neoplastic and non-neoplastic human thyroid tissue: A study by proton-induced X-ray emissions. Iran J Radiat Res 1(4): 211-216.

28. Boulyga SF, Zhuk IV, Lomonosova EM, Denschlag HO, Zauner S, et al. (1997) Determination of microelements in thyroids of the inhabitants of Belarus by neutron activation analysis using the k0-method. J Radioanal Nucl Chem 222 (1-2): 11-14.

29. Reddy SB, Charles MJ, Kumar MR, Seetharami Reddya B, ChAnjaneyulu et al. (2002) Trace elemental analysis of adenoma and carcinoma thyroid by PIXE method. Nucl Instr Meth Phys Res B 196(3-4): 333-339.

30. Woodard HQ White DR (1986) The composition of body tissues. Brit J Radiol 708: 1209-1218.

31. Neimark II, Timoschnikov VM (1978) Development of carcinoma of the thyroid gland in person residing in the focus of goiter endemic. Problemy Endocrinilogii 24(3): 28-32.

32. Zabala J, Carrion N, Murillo M, Mercedes Quintanaa, José Chirinos, et al (2009) Determination of normal human intrathyroidal iodine in Caracas population. J Trace Elem Med Bio 23(1): 9-14.

33. Forssen A (1972) Inorganic elements in the human body. I. Occurrence of $\mathrm{Ba}, \mathrm{Br}, \mathrm{Ca}, \mathrm{Cd}, \mathrm{Cs}, \mathrm{Cu}, \mathrm{K}, \mathrm{Mn}, \mathrm{Ni}, \mathrm{Sn}, \mathrm{Sr}, \mathrm{Y}$ and $\mathrm{Zn}$ in the human body. Annales Medicinae Experimentalis et Biologiae Fenniae 50(3): 99-162.

34. Kortev AI, Donthov GI, Lyascheva AP (1972) Bioelements and a human pathology. Middle-Ural publishing-house, Sverdlovsk, Russia.

35. Soman SD, Joseph KT, Raut SJ, et al. (1970) Studies of major and trace element content in human tissues. Health Phys 19(5): 641-656.

36. Teraoka H (1981) Distribution of 24 elements in the internal organs of normal males and the metallic workers in Japan. Arch Environ Health 36(4): 155-165.

37. Boulyga SF, Becker JS, Malenchenko AF, et al. (2000) Application of ICPMS for multielement analysis in small sample amounts of pathological thyroid tissue. Microchimica Acta 134(3-4): 215-222.

38. Zaichick V (1997) Sampling, sample storage and preparation of biomaterials for INAA in clinical medicine, occupational and environmental health. In: Harmonization of Health-Related Environmental Measurements Using Nuclear and Isotopic Techniques. IAEA, Vienna, p. 123-133. 
39. Zaichick V (2004) Losses of chemical elements in biological samples under the dry ashing process. Trace Elements in Medicine 5: 17-22.

40. Zaichick V, Zaichick S (2000) INAA applied to halogen (Br and I) stability in long-term storage of lyophilized biological materials. J Radioanal Nucl Chem 244(2): 279-281.

41. Zaichick V, Zaichick S (1996) Instrumental effect on the contamination of biomedical samples in the course of sampling. Journal of Analytical Chemistry 51(12): 1200-1205.

42. Zaichick V, Tsislyak YuV (1978) A simple device for bio-sample lyophilic drying. Laboratornoe Delo 2: 109-110.

43. Zaichick V, Tsislyak YuV (1981) A modified adsorptive and cryogenic lyophilizer for biosample concentrations. Laboratornoe Delo 2: 100-101.

44. Zaichick V, Zaichick S (1997) A search for losses of chemical elements during freeze-drying of biological materials. J Radioanal Nucl Chem 218(2): 249-253

45. Zaichick V (1995) Applications of synthetic reference materials in the medical Radiological Research Centre. Fresenius' J Anal Chem 352: 219 223.

46. Zaichick S, Zaichick V (2010) The effect of age and gender on 37 chemical element contents in scalp hair of healthy humans. Biol Trace Elem Res 134(1): 41-54.

47. Zaichick S, Zaichick V (2011) The scalp hair as a monitor for trace elements in biomonitoring of atmospheric pollution. IJEnvH 5(1/2): 106-124.

48. Zaichick S, Zaichick V (2011) INAA application in the age dynamics assessment of $\mathrm{Br}, \mathrm{Ca}, \mathrm{Cl}, \mathrm{K}, \mathrm{Mg}$, Mn, and $\mathrm{Na}$ content in the normal human prostate. J Radioanal Nucl Chem 288(1): 197-202.

49. Zaichick V, Zaichick S (2013) The effect of age on $\mathrm{Br}, \mathrm{Ca}, \mathrm{Cl}, \mathrm{K}, \mathrm{Mg}, \mathrm{Mn}$, and $\mathrm{Na}$ mass fraction in pediatric and young adult prostate glands investigated by neutron activation analysis. J Appl Radiat Isot 82: 14551.

50. Korelo AM, Zaichick V (1993) Software to optimize the multielement INAA of medical and environmental samples. In: Activation Analysis in Environment Protection. Dubna, Russia; Joint Institute for Nuclear Research: 326-332.

51. Zaichick V, Zaichick S (2017) Age-related changes of Ag, Co, Cr, Fe, Hg, $\mathrm{Rb}, \mathrm{Sb}, \mathrm{Sc}, \mathrm{Se}$, and $\mathrm{Zn}$ contents in intact thyroid of males investigated by neutron activation analysis. Current Trends in Biomedical Engineering and Biosciences 4.4: 555644.

52. Zaichick V, Zaichick S (2017) Age-related changes of Ag, Co, Cr, Fe, Hg, $\mathrm{Rb}, \mathrm{Sb}, \mathrm{Sc}, \mathrm{Se}$, and $\mathrm{Zn}$ contents in intact thyroid of females investigated by neutron activation analysis. Gerontology and Geriatric Medicine 3: 015.

53. Zaichick V, Zaichick S (2017) Age-related changes of some trace element contents in intact thyroid of males investigated by energy dispersive X-ray fluorescent analysis. MOJ Gerontol Ger 1(5): 00028.

54. Zaichick V, Zaichick S (2017) Age-related changes of some trace element contents in intact thyroid of females investigated by energy dispersive X-ray fluorescent analysis. Trends in Geriatric Healthcare 1(1): 31-38.

55. Katoh Y, Sato T, Yamamoto Y (2002) Determination of multielement concentrations in normal human organs from the Japanese. Biol Trace Elem Res 90(1-3): 57-70.

56. Schroeder HA, Tipton IH, Nason AP (1972) Trace metals in man: strontium and barium. J Chron Dis 25(9): 491-517.

57. Maschkovsky MD (2005) The sedatives. In: The Medicaments. 15th Ed. Novaya Volna, Moscow, p. 72-86.

58. Pavelka S (2016) Radiometric determination of thyrotoxic effects of some xenobiotics. Rad Appl 1.2: 155-158.

59. Schwarza C, Leichtle AB, Arampatzisc S, et al. (2012) Thyroid function and serum electrolytes. Swiss Med Wkly 142: w13669.

60. Ashmaik AS, Gabra HM, Elzein AOM, et al. (2013) Assessment of Serum Levels of Calcium and Phosphorous in Sudanese Patients with Hypothyroidism. AJBPS 03(25): 21-26.

61. Sidhu GK, Malek R, Khubchandani A, et al. (2016) Assessment of variations in serum Phosphorus, Calcium, Sodium and Potassium levels in hypothyroid patients. Int J Int Med Res 3(3): 26-29.

62. Moncayo R, Moncayo $\mathrm{H}$ (2017) A post-publication analysis of the idealized upper reference value of $2.5 \mathrm{mIU} / \mathrm{L}$ for TSH: Time to support the thyroid axis with magnesium and iron especially in the setting of reproduction medicine. BBA Clin 7: 115-119.

63. Jiménez A (1997) Changes in bioavailability and tissue distribution of selenium caused by magnesium deficiency in rats. J Am Coll Nutr $16: 175-180$

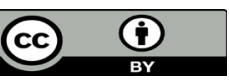

This work is licensed under Creative Commons Attribution 4.0 License

To Submit Your Article Click Here: Submit Article

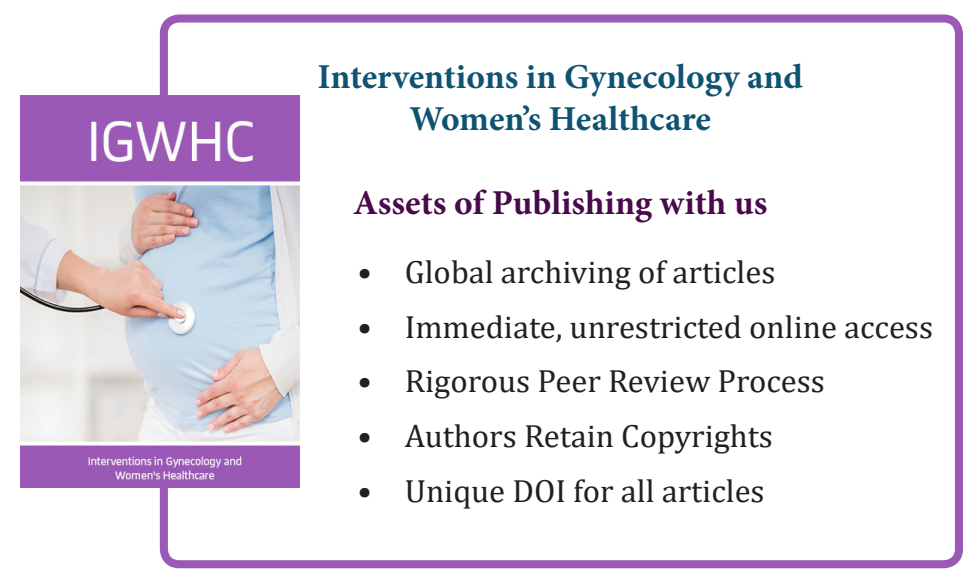

